Acta vet. scand. 1974, 15, 198-205.

From the State Veterinary Serum Laboratory, Department for Jutland, Århus, Denmark.

\title{
INDIRECT FLUORESCENT ANTIBODY TECHNIQUES FOR DEMONSTRATION OF TROUT VIRUSES AND CORRESPONDING ANTIBODY
}

\author{
By \\ P. E. Vestergård Jørgensen
}

\begin{abstract}
JØRGENSEN, P. E. VESTERGARD: Indirect fluorescent antibody techniques for demonstration of trout viruses and corresponding antibody. Acta vet. scand. 1974, 15, 198-205. - Two variations of the indirect fluorescent antibody technique (FA'T) have been utilized in the work concerning two important virus diseases of trout, viral haemorrhagic septicaemia (VHS) and infectious pancreatic necrosis (IPN). A "two layer" indirect FAT allowed demonstration of the respective viruses in cell cultures and a "three layer" indirect FAT allowed demonstration of trout antibody to the viruses. Antibody, by means of the latter technique, could be demonstrated only in artificially immunized trout.
\end{abstract}

trout viruses; trout antibody; indirect

fluorescent antibody techniques.

Direct fluorescent antibody techniques (FAT) for demonstration of the virus of viral haemorrhagic septicaemia (VHS) and infectious pancreatic necrosis (IPN) have previously been described (Jørgensen \& Meyling 1972, Grauballe 1972). Staining of the two viruses by those techniques requires the use at low dilution of a fluoresceinisothiocyanate (FITC) labelled antiserum to each virus. In the present experiment an indirect FAT has been developed in which a FITC labelled swine antiserum to rabbit IgG will do for demonstration of both viruses, and which is more economic as regards viral antisera. Additionally, an indirect FAT has been developed which allows demonstration of antibody to the two viruses in trout serum. 


\section{MATERIAL AND METHODS}

Virus infected cell cultures

Cultures of FHM (Gravell \& Malsberger 1965) or RTG-2 cells (Wolf \& Quimby 1962) on 22 by $9 \mathrm{~mm}$ cover glasses (18 such in a glass Petri dish with a diameter of $10 \mathrm{~cm}$ ) were infected with dilutions of Egtved virus, strain No (serologically related to the reference strain F-1 (Jensen 1965)) or IPN virus, strain Sp or Ab (Jørgensen 1972 a). After infection the cultures were covered with a semisolid overlay medium containing $2 \%$ methyl cellulose or $0.15 \%$ agar ( $\mathrm{pH} 7.6$ to 7.8 ). After incubation at $15^{\circ} \mathrm{C}$ for 24 to $48 \mathrm{hrs}$. the overlay medium was removed by suction and the cell sheets rinsed three times in PBS ( $\mathrm{pH} 7.4$ ). Subsequently the cultures were fixed for $10 \mathrm{~min}$. in acetone and stored at $-20^{\circ} \mathrm{C}$ until used. The cell culture medium used throughout the experiment was Eagle's MEM with $10 \%$ foetal bovine serum. During outgrowth the buffer was bicarbonate $\left(\mathrm{CO}_{2}\right.$-incubator), during plaque formation bicarbonate plus tris.

\section{Rabbit antisera}

Sera from rabbits immunized with Egtved or IPN virus as previously described (Jørgensen 1969,1972 a) were used in dilution $1: 100$.

Antiserum to trout immunoglobulin was obtained by immunizing rabbits with purified immunoglobulin from trout inoculated with IPN virus (Jørgensen 1973). The working dilution of this antiserum was $1: 64$.

\section{Trout sera}

The following sera were examined for the presence of FA stainable antibody: 1, monthly individual serum samples from three trout immunized with Egtved virus (Jørgensen 1971); 2 , serum pools from trout immunized with IPN virus (Jørgensen 1973 ) ; 3, five serum pools from trout exposed to natural infection with Egtved virus in five Danish trout farms where VHS is endemic. Neutralizing antibody to Egtved virus has not yet been demonstrable in such sera (Jørgensen 1971); 4, two pools of trout serum with high titres of neutralizing antibody to IPN virus, one originating from an IPN attacked trout farm, KiMs, the other from an "IPN-free” farm, RaMs (Jørgensen 1973).

The trout sera had been kept at $-20^{\circ} \mathrm{C}$ for up to five years. 
Conjugate

FITC labelled swine antiserum to rabbit IgG was obtained commercially (Dakopatts $\mathrm{A} / \mathrm{S}$, Copenhagen) and used at a 1:50 dilution.

Technique for virus dentonstration ("two layer" indirect FAT)

Fixed cell cultures with virus plaques were covered with viral antiserum and incubated for half an hour in a moist chamber at $37^{\circ} \mathrm{C}$. After rinsing in PBS ( $\mathrm{pH} \mathrm{7.4)} \mathrm{for} \mathrm{half} \mathrm{an} \mathrm{hour} \mathrm{(three}$ changes) the cultures were covered with conjugate and again incubated as above. Following another rinse as above the cultures were mounted in a mixture of glycerol and PBS ( $\mathrm{pH} \mathrm{7.4)} \mathrm{(Gold-}$ man 1968) and examined by fluorescence microscopy as previously described (Jørgensen $1972 \mathrm{~b}$ ).

Technique for demonstration of trout antibody ("three layer" indirect FAT)

Fixed cell cultures with virus plaques were treated as above (incubated and subsequently rinsed) with the following reagents in the order mentioned: 1, trout serum; 2, rabbit antiserum to trout immunoglobulin; 3, conjugate. Mounting and microscopy was carried out as described above.

\section{Controls}

Normal rabbit and trout serum served as specificity controls.

\section{RESULTS}

It was possible to demonstrate all of the three examined virus strains in cell cultures by means of the "two layer" indirect FAT (Table 1). Egtved virus was stained only after treatment with anti-Egtved serum; the two IPN virus strains, $S p$ and $A b$, were stained only after treatment with an IPN antiserum. Antisera against strains $\mathrm{Sp}$ and $\mathrm{Ab}$ were bath cross reactive since they induced staining also of the heterologous IPN virus strain, although at a lower level of fluorescence than with the homologous IPN virus strain.

FA stainable antibody could be demonstrated by the "three layer" indirect FAT in serum from trout artificially immunized with Egtved or IPN virus (Tables 2 and 3) but not in any of the other trout sera examined. 
T a b l e 1. Staining of Egtved and IPN virus in cell cultures by means of a "two layer" indirect fluorescent antibody technique.

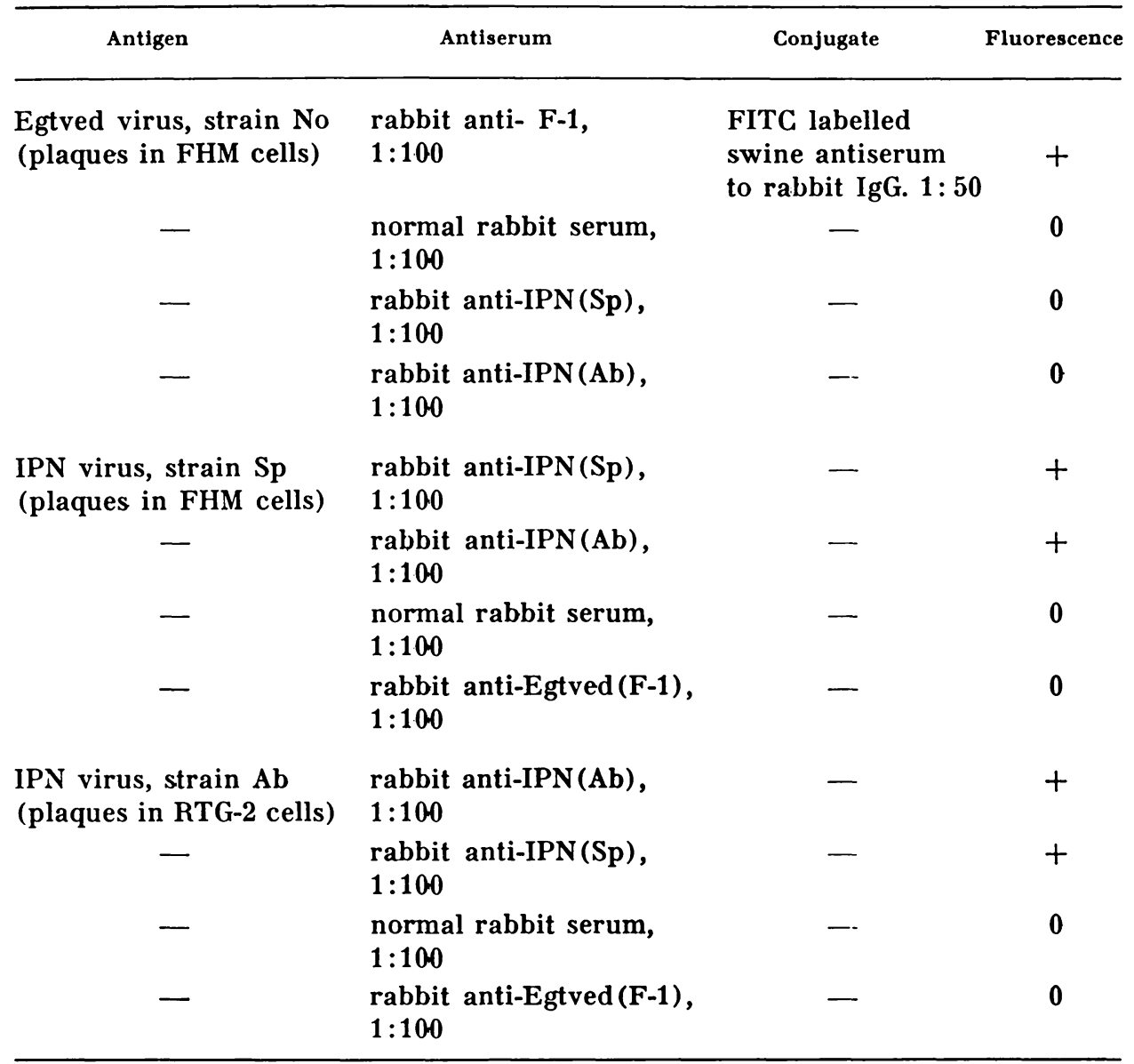

\section{DISCUSSION}

The semisolid overlay media used in this experiment proved to be effective plaquing media and yet were easily removable by suction and washing. The latter feature means that the cultures could be efficiently rinsed before fixation, unlike cultures covered with a solid overlay medium.

The use of cultures with virus plaques led to an easily observable contrast between the bright fluorescence from infected cells (areas with the characteristic shape of plaques) and the slight fluorescence from normal cells (between the plaques) 
Table 2. Demonstration of trout antibody by means of a "three layer" indirect fluorescent antibody technique.

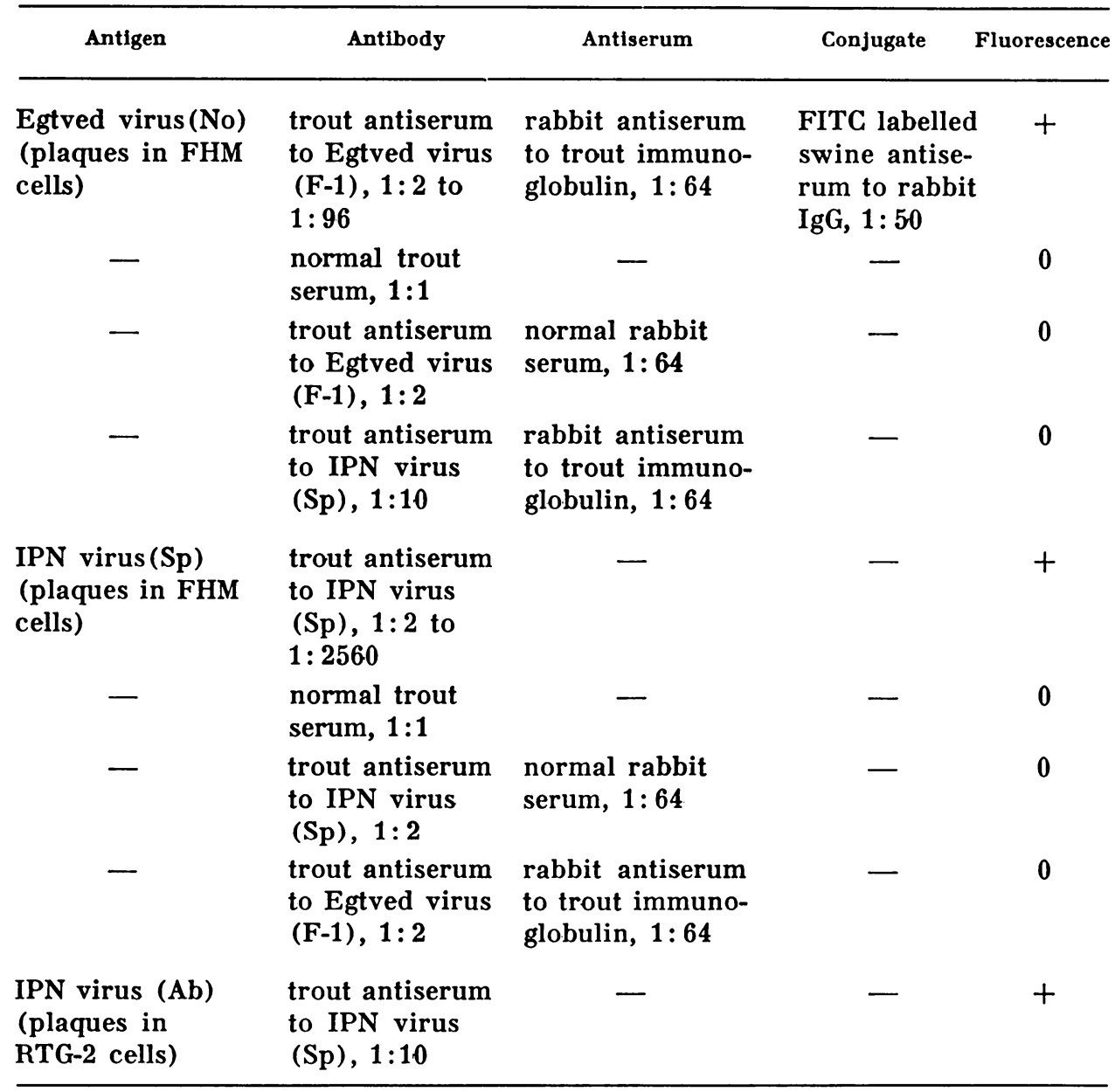

caused by antibody to cell material or by non specific binding of antibody.

By direct FAT, IPN virus, strain Ab, could not be stained by heterologous antiserum conjugate (Jørgensen $1972 \mathrm{~b}$ ), whereas in the present experiment both strains of IPN virus could be stained after treatment with heterologous antiserum. Besides, the background fluorescence was less pronounced in the indirect than in the direct FAT, probably due to the higher serum dilution used. The indirect FAT therefore would seem to be very well fitted for identification of IPN and Egtved virus. 
Table 3. Demonstration of antibody in trout immunized with Egtved virus (repeated injections) or IPN virus (one injection).

\begin{tabular}{|c|c|c|c|}
\hline & $\begin{array}{l}\text { Time after first } \\
\text { virus injection }\end{array}$ & $\begin{array}{l}\text { Neutralizing } \\
\text { antibody }\end{array}$ & $\begin{array}{l}\text { Antibody stain- } \\
\text { able by means } \\
\text { of indirect FAT }\end{array}$ \\
\hline $\begin{array}{l}\text { Egtved } \\
\text { virus }\end{array}$ & $\begin{aligned} 1 & \text { month } \\
2 & \text { months } \\
3 & - \\
4 & - \\
5 & - \\
6 & - \\
7 & - \\
8 & - \\
9 & - \\
10 & - \\
11 & - \\
12 & -\end{aligned}$ & $\begin{array}{l}0 \\
0 \\
0 \\
0 \\
0 \\
0 \\
0 \\
0 \\
0 \\
0 \\
0 \\
+(1: 16)^{*}\end{array}$ & $\begin{array}{l}0 \\
0 \\
0 \\
0 \\
0 \\
0 \\
+ \\
+ \\
+(1: 96) \ldots \ldots \\
+ \\
+ \\
+\end{array}$ \\
\hline $\begin{array}{l}\text { IPN } \\
\text { virus }\end{array}$ & $\begin{array}{rc}3 & \text { weeks } \\
6 & - \\
8 & - \\
12 & - \\
13 & -\end{array}$ & $\begin{array}{l}0 \\
+ \\
+(1: 4100) * \\
+ \\
+\end{array}$ & $\begin{array}{l}0 \\
+ \\
+\quad(1: 2560)^{* *} \\
+ \\
+\end{array}$ \\
\hline
\end{tabular}

* $50 \%$ end point titre in tubes.

* * $50 \%$ plaque-reduction titre.

*** highest serum dilution yielding fluorescence.

In one trout, FA stainable antibody to Egtved virus could be demonstrated five months earlier than neutralizing antibody, i.e., seven months after the first virus injection. The remaining two trout did not develop any of the two types of antibody (Jørgensen 1971). FA stainable antibody to IPN virus could be demonstrated in serum pools six weeks after the virus injection. At that time a rise in the titre of neutralizing antibody could also be demonstrated (Jørgensen 1973).

The "three layer" indirect FAT did not allow demonstration of antibody in trout exposed to natural infection with the viruses, not even in trout which contained neutralizing antibody to IPN virus at titres similar to those observed in the artificially immunized trout (1:3000 to $1: 4000$ ) (Jørgensen 1973). It thus appears that the chemical structure of neutralizing antibody in artificially immunized trout must differ in some respect from that of neu- 
tralizing antibody in trout exposed to natural infection. The difference may be caused by the use of adjuvant in the immunization process, but is nevertheless surprising, since it has previously been found (Jørgensen 1973) that the two "types" of antibody appeared to belong to the same immunoglobulin class.

\section{REFERENCES}

Goldman, M.: Fluorescent Antibody Methods. Academic Press, New York and London 1968, p. 149.

Grauballe, $P$. C.: Infektiøs pankreasnekrose. En ny sygdom i Danmark hos laksefisk. Diagnostiske og ætiologiske unders $\varnothing$ gelser. (Infectious pancreatic necrosis. A new disease of salmonids in Denmark. Diagnostic and aetiological investigations). Licentiatafhandling. Den Kgl. Veterinær- og Landbohøjskole, København 1972, pp. 1-63.

Gravell, M. \& R. G. Malsberger: A permanent cell line from the fathead minnow (Pimephales promelas). Ann. N.Y. Acad. Sci. 1965, 126, $555-565$.

Jensen, M. H.: Research on the virus of Egtved disease. Ann. N.Y. Acad. Sci. 1965, 126, 422-426.

Jørgensen, P. E. Vestergård: Serological identification of Egtved virus. Bull. Off. int. Epiz. 1969, 69, 985-989.

Jørgensen, P. E. Vestergård: Egtved virus: Demonstration of neutralizing antibodies in artificially infected rainbow trout (Salmo gairdneri). J. Fish Res. Bd. Canada 1971, 28, 875-877.

Jørgensen, P. E. Vestergård: Freund's adjuvants: Their influence on the specificity of viral antisera. Acta path. microbiol. scand. Section B. 1972 a, 80, 931-933.

Jørgensen, P. E. Vestergård: Egtved virus: Antigenic variation in 76 virus isolates examined in neutralization tests and by means of the fluorescent antibody technique. In "Symp. zool. Soc. London No. 30". I. Mawdsley-Thomas, ed. Academic Press, London and New York $1972 \mathrm{~b}, 333-340$.

Jørgensen, P. E. Vestergård: The nature and biological activity of IPN virus neutralizing antibodies in normal and immunized rainbow trout. Arch. ges. Virusforsch. 1973, 42, 9-20.

Jørgensen, P. E. Vestergård \& A. Meyling: Egtved virus: Demonstration of virus antigen by the fluorescent antibody technique in tissues of rainbow trout affected by viral haemorrhagic septicaemia and in cell cultures infected with Egtved virus. Arch. ges. Virusforsch. 1972, 36, 115-122.

Wolf, K. \& M. C. Quimby: Established eurythermic line of fish cells in vitro. Science 1962, 135, 1065-1066. 


\section{SAMMENDRAG}

Indirekte immunfluorescens-teknik til påvisning af фrredvirus og фrredantistof.

To ørredpatogene virus (Egtved og IPN virus) er påvist $i$ inficerede cellekulturer ved hjælp af en "to-lags“ indirekte immunfluorescensteknik. Ved hjælp af en „tre-lags“ indirekte immunfluorescensteknik kunne antistof overfor de pågældende virus påvises tidligere end eller samtidig med neutraliserende antistof i serum fra kunstigt immuniserede $\emptyset$ rreder. Metoden tillod ikke påvisning af antistof i фrreder udsat for naturlig smitte med Egtved eller IPN virus.

(Received November 26, 1973).

Reprints may be requested from: P. E. Vestergård Jørgensen, State Veterinary Serum Laboratory, Dept. for Jutland, Hangøvej 2, DK-8200 Århus N, Denmark. 